\title{
PARAMETRIC AND NON-PARAMETRIC ANALYSIS FOR DETERMINING THE ADAPTABILITY AND STABILITY OF SOYBEAN GENOTYPES IN THREE SOWING PERIODS
}

\author{
ANÁLISES PARAMÉTRICAS E NÃO PARAMÉTRICAS PARA DETERMINAÇÃO DA \\ ADAPTABILIDADE E ESTABILIDADE DE GENÓTIPOS DE SOJA EM TRÊS \\ ÉPOCAS DE SEMEADURA
}

\author{
Fernanda Neves ROMANATO ${ }^{1}$; Osvaldo Toshiyuki HAMAWAKI ${ }^{2}$; \\ Larissa Barbosa de SOUSA ${ }^{2}$; Ana Paula Oliveira NOGUEIRA ${ }^{3}$; \\ Dão Pedro de Carvalho NETO ${ }^{4}$; Carla Cristina Rodrigues BORGES ${ }^{5}$; \\ Cristiane Divina Lemes HAMAWAKI ${ }^{6}$; Raphael Lemes HAMAWAKI \\ 1. Mestre em Agronomia, Universidade Federal de Uberlândia - UFU, Uberlândia, MG, Brasil. ferneves_romanato@hotmail.com; \\ 2. Professor, Doutor, Instituto de Ciências Agrárias - ICIAG, Universidade Federal de Uberlândia - UFU, Uberlândia, MG, Brasil. \\ hamawaki@umuarama.ufu.br; 3. Professora, Doutora, Instituto de Genética e Bioquímica - UFU, Uberlândia, MG, Brasil; 4. Mestrando \\ em Engenharia de Bioprocessos e Biotecnologia, Universidade Federal do Paraná - UFPR, Curitiba, PR, Brasil; 5. Mestre em Ecologia \\ e Conservação dos Recursos Naturais - UFU, Uberlândia, MG, Brasil; 6. Professora da UNIPAC, Araguari, MG, Brasil; 7. Doutorando \\ em Ciências Agrícolas, Southern Illinois University, Carbondale, IL, EUA
}

\begin{abstract}
The use of different evaluation methods of adaptability and stability in a breeding program is essential to obtain more accurate results of the lines that have been studied. The purpose of this research is to study the adaptability and stability of 25 soybean lines derived from the soybean breeding program, and for that, it was used parametric and non-parametric analysis at the Federal University of Uberlandia. The experiment was set up in randomized complete block design with three replications in three sowing periods (November 2006, November 2007 and November 2008) and conducted in Campo Alegre de Goias, Brazil. Thirty soybean genotypes were evaluated, including 25 late-cycle lines and five cultivars (BRS/MG Garantia, UFUS Impacta, UFUS Xavante UFUS Milionária and M-Soy 8914) as controls). Grain productivity was determined for each block. The average yield was $3104.201 \mathrm{~kg} \mathrm{ha}^{-1}$. Adaptability and stability were determined using Eberhart and Russel (1966), Lin and Binns (1988) modified by Carneiro (1998) and Centroide (ROCHA, 2005) methods. The UFUS 6 and UFUS 21 lines and the UFUS Impacta and UFUS Xavante cultivars stood out because they had the highest average grain yield, highest adaptability and stability regardless of evaluation method.
\end{abstract}

KEYWORDS: Glycine max. Grain yield. Genotype x Environment Interaction.

\section{INTRODUCTION}

Soybeans are one of the most important crops in the world and in Brazilian agribusiness. Demand for soybeans increases every year due to varied uses, which include animal feed, biodiesel, cooking oil, dietary staples and cosmetics. In Brazil, soybean productivity in the 2015/2016 crop is estimated at $3073 \mathrm{~kg} \mathrm{ha}^{-1}$ (CONAB, 2016).

Behavior of soybean cultivars can vary by location and year. These differences are usually influenced by interactions between genotype and environment $\left(\begin{array}{lll}G & x & E\end{array}\right)$. The expression of the productive potential of a soybean crop is dependent on genetic and environmental factors and the interactions between them. This complicates the selection and evaluation of the productive potential of genotypes. Therefore, extensive evaluations are needed to identify genotypes with superior productivity and production stability given a range of climates, soil, pests and diseases (POLIZEL et al., 2013).

Adaptability is defined as the ability of a genotype to take advantage of environmental stimuli, whereas stability is defined as the ability to demonstrate highly predictable behavior given certain environment stimuli (CRUZ et al., 2012).

Analyses of adaptability and stability are statistical procedures that identify stable cultivars that respond predictably to environmental variation. These analyses include the Centroide (ROCHA, 2005), Lin and Binns (1988) modified by Carneiro (1998), and Eberhart and Russell (1966) methods.

The Centroide (ROCHA et al., 2005) and Lin and Binns (1988) methods are nonparametric ways of identifying genotypes based on environmental variation without having to analyze parameters (NASCIMENTO, 2009). The parametric Eberhart and Russel (1966) method uses linear regression to link the average yield of each genotype 
with an environmental index provided by the average response of the same genotypes.

Several studies have identified lines with broad adaptability and stability. One such study by Franco and Hamawaki (2009) investigated the adaptability and stability of soybean genotypes in the 2004/2005 crop in Goias, Brazil. Another study by Marques et al. (2011) used Carneiro (1998) modified Lin and Binns (1988), Eberhart and Russell (1966), and the Centroide (ROCHA et al., 2005) methods to evaluate the adaptability and stability of soy genotypes at different sowing dates.

Barros et al. (2010) studied the analysis of soybean (Glycine max L.) adaptability and stability in Mato Grosso, Brazil and concluded that different nonparametric methods produce similar results and could be used to successfully identify genotypes with greater productivity, stability and adaptability.

The aim of this study was to evaluate by parametric and non-parametric methods to study the adaptability and stability of 25 soybean lines from the Soybean Breeding Program at the Federal University of Uberlandia.

\section{MATERIAL AND METHODS}

Performed our experiments in red-yellow dystrophic Oxisol at the Santa Fe farm in Campo Alegre de Goias, Brazil (17 $67^{\prime}$ S latitude and $47^{\circ} 62^{\prime}$ W longitude, altitude $877 \mathrm{~m})$. The experiment was set up in randomized complete block design with three replications. The treatments consisted of thirty soybean genotypes (25 late-cycle lines and five commercial cultivars: BRSMG Garantia, UFUS Impacta, UFUS Xavante UFUS Milionária and MSoy 8914). Seeds were sown in three consecutive years (November 2006, November 2007, and November 2008).

Each experimental unit consisted of four rows of soybeans ( $5 \mathrm{~m}$ long, spaced $0.5 \mathrm{~m}$ apart). The two outer rows and $0.5 \mathrm{~m}$ at each end of the plot were not evaluated, leaving two rows of $4.0 \mathrm{~m}$ (i.e. plots of $4.0 \mathrm{~m}^{2}$ ).

Grain productivity (GP) (kg ha $\left.{ }^{-1}\right)$ was evaluated by manually harvesting each $4.0 \mathrm{~m}^{2}$ plot. After harvesting, the plants were threshed and the seeds were manually prepared for weighing. Next, the data were transformed from grams per plot to $\mathrm{kg}$ $\mathrm{ha}^{-1}$ and corrected for moisture (13\%) using the following formula:

$\mathrm{FW}=\frac{\mathrm{IW} \times(100-\mathrm{IM})}{100-\mathrm{IF}}$

Where:

FW is the corrected sample weight, IW is initial sample weight, IM is initial sample moisture and IF is the final sample moisture $(13 \%)$.

Statistical analysis was by individual and joint analysis of variance (F-test). Adaptability and stability analyses were then processed using GENES software (CRUZ, 2009) and the parametric methods proposed by Eberhart and Russell (1966) and nonparametric methods proposed by Lin and Binns (1988) modified by Carneiro (1998), and Centroide (ROCHA et al., 2005)

\section{RESULTS AND DISCUSSION}

The experimental coefficient of variation (CV) from the joint analysis of variance was $17.65 \%$ (Table 1). Dias et al. (2009) found a CV of $22.52 \%$ in a study on phenotypic adaptability and stability of soybean grain yield in Ceara, Brazil.

Table 1. Joint analysis of variance summary for the grain productivity $\left(\mathrm{kg} \mathrm{ha}^{-1}\right)$ of 25 soybean genotypes and five cultivars in the 2006/2007, 2007/2008 and 2008/2009 crops, Campo Alegre de Goias, Brazil.

\begin{tabular}{ccc}
\hline SOURCE OF VARIATION & DEGREES OF FREEDOM & MEAN SQUARE \\
\hline Bloks/Years & 6 & 1244877.66300 \\
Genotypes & 29 & $462005.66356^{*}$ \\
Years & 2 & $1483244.96893^{\mathrm{ns}}$ \\
Genotypes X Years & 58 & $390961.67482^{+}$ \\
Error & 174 & 300232.85293 \\
\hline Average & & 3104.20 \\
$\mathbf{C V}(\boldsymbol{\%})$ & 17.65 \\
$\mathbf{h}^{\mathbf{2}}(\boldsymbol{\%})$ & 35.05 \\
\hline
\end{tabular}

${ }^{\mathrm{ns}}$ Not significant, ${ }^{*}$ Significant at $5 \%$ probability, ${ }^{+}$Significant at $10 \%$ probability (F test). 
According to Carvalho et al. (2003), the maximum coefficient of variation for grain productivity, which is strongly influenced by the environment, is $16 \%$. Average grain productivity was $3104.2 \mathrm{~kg} \mathrm{ha}^{-1}$ and the coefficient of genotype determination was $35.05 \%$. These results demonstrate strong environmental influence, which is common for polygenic traits. $\mathrm{G} \times \mathrm{A}$ interaction was significant $(\mathrm{p}<0.10, \mathrm{~F}$-test) (Table 1$)$.

Oliveira et al. (2012) studied the adaptability and stability of soybean productivity in two regions and found significant genotype $\mathrm{x}$ environment interaction $(\mathrm{CV}=4.9 \%)$. Their results show that genotype behavior varies due to environmental change and that the study of phenotype adaptability and stability is justified.

Franco and Hamawaki (2009) found a CV of $17.66 \%$ in a joint analysis of variance of grain productivity in 32 late-cycle soybean varieties from two sowing dates and five locations in the 2004/2005 crop.

Table 2 shows the adaptability and stability parameters from the Eberhart and Russel (1966) and Lin and Binns (1988) modified by Carneiro (1998)methods.

Table 2. Average grain productivity $\left(\mathrm{kg} \mathrm{ha}^{-1}\right)$ and estimates of the adaptability and stability parameters using the Eberhart and Russel (1966) and Lin and Binns (1988) modified by Carneiro (1998) methods for 25 lines and 5 cultivars of soybeans from three crops (2006/2007, 2007/2008 and 2008/2009) in Campo Alegre de Goias, Brazil.

\begin{tabular}{|c|c|c|c|c|c|c|c|}
\hline \multirow[t]{2}{*}{ GENOTYPES } & \multirow[t]{2}{*}{ AVERAGE } & \multicolumn{3}{|c|}{$\begin{array}{c}\text { EBERHART AND RUSSEL } \\
(1966)\end{array}$} & \multicolumn{3}{|c|}{$\begin{array}{l}\text { LIN AND BINNS (1988) MODIFIED BY } \\
\text { CARNEIRO (1998) }\end{array}$} \\
\hline & & $\beta_{1}$ & $\sigma_{\mathrm{di}}^{2}$ & $\mathrm{R}^{2}$ & $\mathrm{Pi}_{\text {general }}$ & $\mathrm{Pi}_{\text {favorable }}$ & $\mathrm{Pi}_{\text {unfavorable }}$ \\
\hline UFUS-01 & 3326.42 & $-1.80^{\mathrm{ns}}$ & $15122.39^{\text {ns }}$ & 48.17 & 296563.49 & 787048.22 & 51321.13 \\
\hline UFUS-02 & 3139.34 & $0.93^{\mathrm{ns}}$ & $-97132.34^{\mathrm{ns}}$ & 90.71 & 306473.87 & 536765.42 & 191328.10 \\
\hline UFUS-03 & 3315.69 & $0.51^{\mathrm{ns}}$ & $-61203.60^{\mathrm{ns}}$ & 17.85 & 202912.87 & 426102.96 & 91317.82 \\
\hline UFUS-04 & 3168.35 & $-1.38^{\mathrm{ns}}$ & $-71556.94^{\mathrm{ns}}$ & 68.74 & 367309.03 & 911250.00 & 95338.55 \\
\hline UFUS-05 & 3132.81 & $-1.11^{\mathrm{ns}}$ & $-76551.20^{\mathrm{ns}}$ & 63.25 & 378808.69 & 905010.22 & 115707.92 \\
\hline UFUS-06 & 3232.47 & $1.59^{\mathrm{ns}}$ & $-99816.94^{\mathrm{ns}}$ & 99.69 & 228494.32 & 358109.02 & 163686.98 \\
\hline UFUS-07 & 2929.93 & $-3.09 * *$ & $-81308.09^{\mathrm{ns}}$ & 94.36 & 662189.23 & 1695874.20 & 145346.75 \\
\hline UFUS-08 & 3152.12 & $2.48^{\mathrm{ns}}$ & $-85026.49^{\mathrm{ns}}$ & 93.11 & 280392.73 & 314834.35 & 263171.92 \\
\hline UFUS-09 & 3648.96 & $4.49 * *$ & $-85825.27^{\mathrm{ns}}$ & 97.90 & 48836.78 & 0.00 & 73255.18 \\
\hline UFUS-10 & 3288.44 & $6.15 *$ & $-93954.06^{\mathrm{ns}}$ & 99.51 & 246773.42 & 6485.47 & 366917.40 \\
\hline UFUS-11 & 3252.57 & $-0.77^{\mathrm{ns}}$ & $-97029.11^{\mathrm{ns}}$ & 86.60 & 278679.90 & 691405.68 & 72317.01 \\
\hline UFUS-12 & 2562.27 & $-0.15^{\mathrm{ns}}$ & $-80918.59^{\mathrm{ns}}$ & 3.50 & 939679.63 & 1572030.46 & 623504.21 \\
\hline UFUS-13 & 3073.26 & $-0.85^{\mathrm{ns}}$ & $-88026.34^{\mathrm{ns}}$ & 66.42 & 413595.29 & 933893.44 & 153446.21 \\
\hline UFUS-14 & 3005.55 & $1.47^{\mathrm{ns}}$ & $-70329.95^{\mathrm{ns}}$ & 70.66 & 412227.64 & 593850.18 & 321416.37 \\
\hline UFUS-15 & 2807.17 & $-2.17^{\mathrm{ns}}$ & $-85698.36^{\mathrm{ns}}$ & 91.49 & 730733.22 & 1670389.86 & 260904.90 \\
\hline UFUS-16 & 2961.33 & $0.5919^{\mathrm{ns}}$ & $-76623.45^{\mathrm{ns}}$ & 32.99 & 468730.95 & 799880.60 & 303156.12 \\
\hline UFUS-17 & 3091.51 & $1.61^{\mathrm{ns}}$ & $-64610.90^{\mathrm{ns}}$ & 70.73 & 336125.13 & 483475.50 & 262449.94 \\
\hline UFUS-18 & 3007.02 & $4.78 * *$ & $746656.57^{++}$ & 47.08 & 551273.90 & 178889.72 & 737465.99 \\
\hline UFUS-19 & 3169.37 & $-0.72^{\mathrm{ns}}$ & $-97515.53^{\mathrm{ns}}$ & 87.09 & 333608.73 & 783568.38 & 108628.91 \\
\hline UFUS-20 & 2848.30 & $1.47^{\mathrm{ns}}$ & $-58917.05^{\mathrm{ns}}$ & 63.47 & 566668.04 & 777783.02 & 461110.55 \\
\hline UFUS-21 & 3240.17 & $1.99^{\mathrm{ns}}$ & $-100060.11^{\mathrm{ns}}$ & 99.99 & 218603.54 & 302468.27 & 176671.18 \\
\hline UFUS-22 & 3062.20 & $-2.37^{\mathrm{ns}}$ & $-27909.28^{\mathrm{ns}}$ & 72.03 & 506029.07 & 1285932.19 & 116077.51 \\
\hline UFUS-23 & 3057.90 & $3.69^{\mathrm{ns}}$ & $-98390.78^{\mathrm{ns}}$ & 99.63 & 355645.04 & 251524.87 & 407705.13 \\
\hline UFUS-24 & 2968.07 & $-0.42^{\mathrm{ns}}$ & $18547.47^{\mathrm{ns}}$ & 4.58 & 505406.85 & 990396.76 & 262911.89 \\
\hline UFUS-25 & 2670.97 & $2.11^{\mathrm{ns}}$ & $594942.90^{++}$ & 17.48 & 873863.03 & 883957.97 & 868815.56 \\
\hline BRSMG Garantia & 3287.45 & $-0.33^{\mathrm{ns}}$ & $161045.94^{\mathrm{ns}}$ & 1.34 & 286256.00 & 577830.42 & 140468.79 \\
\hline UFUS Impacta & 3178.38 & $3.56^{\mathrm{ns}}$ & $-57785.60^{\mathrm{ns}}$ & 90.82 & 268673.48 & 184473.45 & 310773.49 \\
\hline UFUS Xavante & 3548.2 & $3.23^{\mathrm{ns}}$ & $-98881.20^{\mathrm{ns}}$ & 99.65 & 61755.26 & 41195.98 & 72034.89 \\
\hline M-Soy 8914 & 3061.55 & $1.27^{\mathrm{ns}}$ & $-85185.12^{\mathrm{ns}}$ & 77.98 & 362939.99 & 566913.72 & 260953.13 \\
\hline UFUS Milionária & 2938.16 & $3.22^{\mathrm{ns}}$ & $-97467.59^{\mathrm{ns}}$ & 99.24 & 459449.51 & 403336.71 & 487505.90 \\
\hline
\end{tabular}

${ }^{\mathrm{ns}}$ not significant, $*$ significant at $5 \%$ probability, ${ }^{* *}$ significant at $1 \%$ probability (t test), ${ }^{++}$significant at $1 \%$ probability (F test), linear regression coefficient $\left(\beta_{1}\right)$. Deviations from linear regression $\left(\sigma_{\text {di }}^{2}\right)$ and the coefficient of determination $\left(R^{2}\right)$. 
According to the Eberhart and Russel (1966) method, an ideal genotype has high grain productivity, equal regression coefficients and insignificant deviation. UFUS 7 had unfavorable environmental adaptability $\left(\beta_{1}\right)<1$ and high stability given its insignificant deviation $\left(\sigma_{\mathrm{di}}^{2}\right)$. On the other hand, UFUS 9, UFUS 10 and UFUS 18 had favorable environmental adaptation given that their $\left(\beta_{1}\right)$ values were significant at 1 and $5 \%$ probability (t-test). However, only UFUS 9 and UFUS 10 had high stability and coefficients of determination greater than $97 \%$. Grain productivity of these lines was 3648.96 and $3288.44 \mathrm{~kg} \mathrm{ha}^{-1}$, respectively.

UFUS 2, UFUS 6, UFUS 8, UFUS 11, UFUS 14, UFUS 15, UFUS 17, UFUS 19, UFUS 21, UFUS 22, UFUS 23 and the UFUS Impacta, UFUS Xavante, M-Soy 8914 and UFUS Milionária cultivars had general adaptability, high stability (Table 2) and coefficients of determination greater than $70 \%$. The Eberhart and Russel (1966) method recommends that coefficients of determination should be greater than $70 \%$.

Marques et al. (2011) used Eberhart and Russell (1966), Carneiro (1998) modified Lin and Binns (1988) and Centroide (ROCHA et al., 2005) methods to evaluate the average behavior, adaptability and stability of seven soybean cultivars at three sow dates in Uberlandia, Brazil. They concluded that the UFUS Xavante cultivar had the highest average grain productivity in the first and second sowings and that significant $G \times A$ interaction suggested that the cultivar had superior performance given environmental fluctuations between sowing dates. It is important for farmers to know the adaptability and stability of genetic material in relation to sowing dates in order to select genotypes that behave predictably and that respond to environmental variation.

According to Lin and Binns (1988) modified by Carneiro (1998), $\mathrm{P}_{\mathrm{i}}$ original should be used as a general criteria for cultivar selection, whereas $\mathrm{P}_{\text {id }}$ should be used for cultivar selection in unfavorable climates and $\mathrm{P}_{\text {if }}$ for favorable climates. In Table 2, shows that UFUS 10, UFUS 18, UFUS 23, UFUS Impacta and UFUS Xavante are appropriate for favorable environments given their lower $\mathrm{Pi}_{\text {favorable }}$ values.

UFUS 3, UFUS 6 and UFUS 21 are adapted to general environments given their lower Pi general values and higher grain productivities of $3315.69 \mathrm{~kg}$ $\mathrm{ha}^{-1}, 3232.47 \mathrm{~kg} \mathrm{ha}^{-1}$, and $3240.17 \mathrm{~kg} \mathrm{ha}^{-1}$, respectively. UFUS 3 , UFUS 4, UFUS 5, UFUS 9, UFUS 11, UFUS 19 and UFUS 22 are best suited to unfavorable climates (Table 2).

According to the Centroide methodology (ROCHA et al., 2005), maximum general adaptability is indicated by the maximum values for all of the environments studied (idiotype I). Idiotypes representing maximum specific adaptability are those with the highest values in favorable environments and lowest values in unfavorable environments (idiotype II) or maximum values in unfavorable environments and minimum values in favorable environments (idiotype III). The idiotype with the lowest adaptability has the lowest values in all of the environments studied (idiotype IV). Table 3 shows these evaluations for the soybean lines and cultivars considered in the present study.

Table 3. Adaptability and stability according to the Centroid methodology for 25 soybean lines and five cultivars from three crops (2006/2007, 2007/2008, and 2008/2009) in Campo Alegre de Goias, Brazil.

\begin{tabular}{lccccc}
\hline \multirow{2}{*}{ GENOTYPES } & \multirow{2}{*}{ CLASSIFICATION } & \multicolumn{4}{c}{ CENTROIDE } \\
\cline { 3 - 6 } & & PROB (I) & PROB (II) & PROB (III) & PROB (IV) \\
\hline UFUS-1 & III & 0.2543 & 0.1362 & 0.4575 & 0.152 \\
UFUS-2 & III & 0.2752 & 0.1989 & 0.3139 & 0.212 \\
UFUS-3 & III & 0.3269 & 0.1725 & 0.3280 & 0.1726 \\
UFUS-4 & III & 0.2324 & 0.1505 & 0.4371 & 0.18 \\
UFUS-5 & III & 0.2336 & 0.1577 & 0.4182 & 0.1904 \\
UFUS-6 & I & 0.3161 & 0.2016 & 0.2885 & 0.1939 \\
UFUS-7 & III & 0.1789 & 0.1426 & 0.4678 & 0.2107 \\
UFUS-8 & I & 0.2928 & 0.2332 & 0.259 & 0.215 \\
UFUS-9 & I & 0.5655 & 0.1599 & 0.1595 & 0.1152
\end{tabular}


Parametric and non-parametric analysis...

ROMANATO, F. N. et al.

$\begin{array}{lccccc}\text { UFUS-10 } & \text { I } & 0.3189 & 0.3142 & 0.1839 & 0.183 \\ \text { UFUS-11 } & \text { III } & 0.2681 & 0.1549 & 0.4051 & 0.1719 \\ \text { UFUS-12 } & \text { IV } & 0.1567 & 0.1879 & 0.2354 & 0.42 \\ \text { UFUS-13 } & \text { III } & 0.2294 & 0.1677 & 0.3944 & 0.2085 \\ \text { UFUS-14 } & \text { III } & 0.2436 & 0.2233 & 0.2816 & 0.2515 \\ \text { UFUS-15 } & \text { III } & 0.1847 & 0.1666 & 0.3785 & 0.2702 \\ \text { UFUS-16 } & \text { III } & 0.2275 & 0.2060 & 0.307 & 0.2595 \\ \text { UFUS-17 } & \text { III } & 0.2689 & 0.2183 & 0.2857 & 0.227 \\ \text { UFUS-18 } & \text { II } & 0.2471 & 0.2990 & 0.2119 & 0.242 \\ \text { UFUS-19 } & \text { III } & 0.2498 & 0.1623 & 0.3995 & 0.1883 \\ \text { UFUS-20 } & \text { IV } & 0.2076 & 0.2295 & 0.2582 & 0.3046 \\ \text { UFUS-21 } & \text { I } & 0.3241 & 0.2089 & 0.2737 & 0.1934 \\ \text { UFUS-22 } & \text { III } & 0.1971 & 0.1411 & 0.4759 & 0.186 \\ \text { UFUS-23 } & \text { II } & 0.2611 & 0.2803 & 0.2235 & 0.2351 \\ \text { UFUS-24 } & \text { III } & 0.2218 & 0.1866 & 0.3469 & 0.2447 \\ \text { UFUS-25 } & \text { IV } & 0.1854 & 0.2458 & 0.2195 & 0.3493 \\ \text { RS/MG Garantia } & \text { III } & 0.2915 & 0.1708 & 0.3563 & 0.1814 \\ \text { UFUS Impacta } & \text { I } & 0.3019 & 0.2584 & 0.2304 & 0.2093 \\ \text { UFUS Xavante } & \text { I } & 0.517 & 0.1635 & 0.1914 & 0.1281 \\ \text { M-Soy 8914 } & \text { III } & 0.2575 & 0.213 & 0.2961 & 0.2334 \\ \text { UFUS Milionária } & \text { II } & 0.2289 & 0.2757 & 0.2255 & 0.2698\end{array}$

Idiotype I = General adaptability, Idiotype II = Adaptability specific to favorable environments, Idiotype III = Adaptability specific to unfavorable environments, Idiotype IV = limited adaptability.

The Centroide method (ROCHA et al., 2005) (Table 3) showed that UFUS 6, UFUS 8 , UFUS 9, UFUS 10 and UFUS 21 lines and UFUS Impacta and UFUS Xavante cultivars have general adaptability (Class I).

UFUS 18, UFUS 23 and UFUS Milionária are classified for favorable environments, whereas UFUS 1, UFUS 2, UFUS 3 , UFUS 4, UFUS 5, UFUS 7 , UFUS 11 , UFUS 13 , UFUS 14 , UFUS 15 , UFUS 16, UFUS 17, UFUS 19, UFUS 22, BRS/MG Garantia and MSOY 8914 are classified for unfavorable environments. UFUS 12, UFUS 20 and UFUS 25 require further study.

Peluzio et al. (2008) studied the adaptability and stability of soybean cultivars from four sowing periods in Tocantins, Brazil and identified eleven unadapted varieties (group IV). Marques et al. (2011) also used the Centroide method (ROCHA et al., 2005) and found three group IV cultivars. Table 3 shows that UFUS 6 , UFUS 21 , UFUS Impacta and UFUS Xavante are classified in the general class (I), corroborating (except for genotype 8) the results of the Eberhart and Russel (1966) and Lin and Binns (1988) modified by Carneiro (1998) methodologies.

Hamawaki et al. (2009) found similar agreement among these methodologies when studying the behavior of two soybean lines in in Goiatuba, Brazil and in the Triângulo Mineiro region of Brazil.

Studies on the adaptability and stability of grain productivity in two soybean-producing regions (OLIVEIRA et al., 2012) observed that Lin and Binns (1988) modified by Carneiro (1998)and the Centroide (1998) methodologies could consistently identify and classify soybean genotypes. Barros et al. (2010) was also able to produce similar genotype classifications with these methodologies when evaluating soybean cultivars in Mato Grosso, Brazil.

Lin and Binns (1988) modified by Carneiro (1998) methodology and the Eberhart and Russel (1966) methodology predominantly agreed on genotype classification. Both methodologies classified UFUS 10 as adapted to favorable environments and UFUS 7 to unfavorable environments. 


\section{CONCLUSIONS}

The UFUS 6 and UFUS-21 lines and the UFUS Impacta and UFUS Xavante cultivars were identified by the Eberhart and Russel (1966), Carneiro (1998) modified Lin and Binns (1988) and Centroide (ROCHA et al., 2005) methodologies for their high average grain productivity, broad adaptability and high stability.

Lin and Binns (1988) modified by Carneiro (1998) method demonstrated that the UFUS 9 and UFUS 10 lines have broad adaptability, high stability and high productivity and consequently, the potential for sowing in different environments.

According to the Centroide method (ROCHA et al., 2005), UFUS 12, UFUS 20 and UFUS 25 are unadapted and require further study.

\section{ACKNOWLEDGEMENTS}

We are grateful for research support from the soybean-breeding program at the Federal University of Uberlandia, for financial support from the Brazilian institution CAPES, CNPq for the financial support of thisstudy (postgraduate scholarship) and FAPEMIG (Foundation for Research Support of the State of Minas Gerais), which promotes encouragement, support and encourage scientific and technological research activities in Minas Gerais, enabling the study by providing financial assistance

RESUMO: A utilização de diferentes métodos para avaliação da adaptabilidade e estabilidade em um programa de melhoramento genético é essencial para a obtenção de resultados mais precisos das linhagens estudadas. O objetivo deste trabalho foi estudar a adaptabilidade e a estabilidade de 25 linhagens de soja oriundas do Programa de Melhoramento de Soja da Universidade Federal de Uberlândia através dos métodos paramétricos e não paramétricos. O experimento foi conduzido em delineamento de blocos completos casualizados, com três repetições, em três épocas de semeadura, em novembro de 2006, novembro de 2007 e novembro de 2008, no município de Campo Alegre de Goiás-GO. Avaliaram-se 30 genótipos de soja, sendo 25 linhagens de ciclo tardio e cinco cultivares como testemunhas (BRS/MG Garantia, UFUS Impacta, UFUS Xavante, UFUS Milionária e M-Soy 8914). Em cada parcela, foi determinada a produtividade de grãos. A média da produtividade foi de $3104,201 \mathrm{~kg} \mathrm{ha}^{-1}$. Para o estudo sobre adaptabilidade e estabilidade utilizaram-se os métodos de Eberhart e Russel (1966), Lin e Binns (1988) modificado por Carneiro (1998) e Centroide (ROCHA, 2005). As linhagens UFUS 6, UFUS 21 e as cultivares UFUS Impacta e UFUS Xavante se destacaram por apresentarem elevadas médias de produtividade de grãos, ampla adaptação e alta estabilidade por todos os métodos estudados

PALAVRAS-CHAVE: Glycine max . Produtividade de grãos. Interação genótipos x Ambientes.

\section{REFERENCES}

BARROS, H. B.; SEDIYAMA, T.; TEXEIRA, R. C.; FIDELIS, R. R.; CRUZ, C. D.; REIS, M. S. Adaptabilidade e estabilidade de genótipos de soja avaliados no estado do Mato Grosso. Ceres, Viçosa, v. 57, n. 3, p. 359-366, 2010. http://www.scielo.br/scielo.php?script=sci_arttext\&pid=S0034-737X2010000300011

CARNEIRO, P. C. S. Novas metodologias de análise da adaptabilidade e estabilidade de comportamento. 1998. 168 f. Tese (Doutorado em Genética e Melhoramento) - Curso de Pós-Graduação em Genética e Melhoramento, Universidade Federal de Viçosa, Viçosa, 1998.

CARVALHO, C. G. P.; ARIAS, C. A. A.; TOLEDO, J. F. F.; ALMEIDA, L. A.; KIHL, R. A. S.; OLIVEIRA, M. S.; HIROMOTO, D. M.; TAKEDA, C. Proposta de classificação dos coeficientes de variação em relação à produtividade e altura da planta de soja. Pesquisa Agropecuária Brasileira, Brasília, v. 3, n. 2, p. 187-193, 2003. http://seer.sct.embrapa.br/index.php/pab/article/view/6559/3616

CONAB. Companhia Nacional de Abastecimento. Acompanhamento da safra brasileira: grãos, sexto levantamento, 2015. Companhia Nacional de Abastecimento. Brasília: Conab, 2016.

CRUZ, C. D.; REGAZZI. A. J.; CARNEIRO. P. C. S. Modelos biométricos aplicados ao melhoramento genético. v. I. 4 ed. Viçosa: Editora UFV, 2012. 514 p. 
CRUZ, C. D. Programa GENES- aplicativo computacional em genética e estatística. Viçosa: UFV, 2009. 648 p.

DIAS, F. T. C.; PITOMBEIRA, J. P.; TEÓFILO, E. M.; BARBOSA, F. S. Adaptabilidade e estabilidade fenotípica para o caráter rendimento de grãos em cultivares de soja para o Estado do Ceará. Ciência Agronômica, Fortaleza, v. 40, n. 1, p. 129-134, 2009.

http://www.ccarevista.ufc.br/seer/index.php/ccarevista/article/view/414/314

EBERHART, S. A.; RUSSELL, W. A. Stability parameters for comparing varieties. Crop Science, Madison, v. 6, n. 1, p. 36-40, 1966. http://dx.doi.org/10.2135/cropsci1966.0011183X000600010011x

FRANCO, P. B.; HAMAWAKI, O. T. Adaptabilidade e estabilidade de genótipos de soja em Goiás no ano 2004/2005. Bioscience Journal, Uberlândia, v. 25, n. 3, p. 51-64, 2009.

http://www.seer.ufu.br/index.php/biosciencejournal/article/view/6919

HAMAWAKI, O. T.; OLIVEIRA NETO, J. O.; REZENDE, D. F.; CUNHA, M. C. G.; LANA, R. M. Q. Comportamento de linhagens de soja no triângulo mineiro e em Goiatuba - GO. Bioscience Journal, Uberlândia, v. 25, n. 5, fev. p. 36-42, 2009.

http://www.seer.ufu.br/index.php/biosciencejournal/article/view/6980

LIN, C.S.; BINNS, M.R. A superiority measure of cultivar performance for cultivar x location data. Canadian Journal of Plant Science, Ottawa, v. 68, n. 1, p. 193-198 1988. http://dx.doi.org/10.4141/cjps88-018

MARQUES, M. C.; HAMAWAKI, O. T.; SEDIYAMA, T.; BUENO, M. R.; REIS, M. S; CRUZ, C. D; NOGUEIRA, A. P. O. Adaptabilidade e estabilidade de genótipos de soja em diferentes épocas de semeadura. Bioscience Journal, Uberlândia, v. 27, n. 1, p. 59-69, 2011.

http://www.seer.ufu.br/index.php/biosciencejournal/article/view/7388.

NASCIMENTO, M.; CRUZ, C. D.; CAMPANA, A. M.; TOMAZ, R. S.; SALAGADO, C. C.; FERREIRA, R. P. Alteração no método centroide de avaliação da adaptabilidade genotípica. Pesquisa Agropecuária Brasileira, Brasília, v. 44, n. 3, p. 263-269, 2009. http://www.scielo.br/scielo.php?pid=S0100204X2009000300007\&script=sci_arttext

OLIVEIRA, L. G.; HAMAWAKI, O. T.; SIMON, G. A.; SOUSA, L. B.; NOGUEIRA, A. P. O.; REZENDE, D. F.; HAMAWAKI, C. D. L. Adaptabilidade e estabilidade da produtividade de soja em duas regiões sojícolas. Bioscience Journal, Uberlândia, v. 28, n. 6, p. 852-861, 2012.

http://www.seer.ufu.br/index.php/biosciencejournal/article/view/14575

PELUZIO, J. M.; FIDELIS, R. R.; GIONGO, P. R.; SILVA, J. C; CAPPELLARI, D.; BARROS, H. B. Análise de regressão e componentes principais para estudo da adaptabilidade e estabilidade em soja. Scientia Agraria, Curitiba, v. 9. n. 4, p. 2008.

POLIZEL, A. C.; JULIATTI, F. C.; HAMAWAKI, O. T.; HAMAWAKI, R. L.; GUIMARAES, S. L. Adaptabilidade e estabilidade fenotípica de genótipos de soja no estado do Mato Grosso. Bioscience Journal, Uberlândia, v. 29. n. 4, p. 910-920, 2013.

http://www.seer.ufu.br/index.php/biosciencejournal/article/viewFile/15079/12905

ROCHA, R. B.; MURO-ABAD, J. I.; ARAUJO, E. F.; CRUZ, C. D. Avaliação do método centróide para estudo de adaptabilidade ao ambiente de clones de Eucalyptus grandis. Ciência Florestal, Santa Maria, v. 15. n. 3, p. 255-256, 2005. http://coral.ufsm.br/cienciaflorestal/artigos/v15n3/A5V15N3.pdf 